\title{
The effect of alkaline hydrolysis of maize on the availability of its nicotinic acid to the pig
}

\author{
BY E. KODICEK \\ Dunn Nutritional Laboratory, University of Cambridge and Medical Research Council \\ AND R. BRAUDE, S. K. KON AND K. G. MITCHELL \\ National Institute for Research in Dairying, University of Reading
}

(Received ro October 1955)

The connexion between pellagra and maize consumption has occupied the interest of many workers for a number of years. It has been suggested that maize owes its pellagragenic property to an imbalance of amino-acids, tryptophan being especially low. 'This imbalance was said to increase the need for nicotinic acid (Krehl, Henderson, de la Huerga \& Elvehjem, 1946; Krehl, 1949). The presence of a 'toxic' factor in maize has also been postulated (Woolley, I946; Borrow, Fowden, Stedman, Waterlow \& Webb, I948). Though this postulate cannot be entirely disregarded, it has not received experimental support in recent years. It is the purpose of this paper to present further evidence for another factor that may contribute to the pellagragenic property of maize, namely the unavailability of the nicotinic acid present in the cereal in 'bound' form.

The observation that 'an unknown substance is present in cereals, giving the $\mathrm{CNBr}-p$-aminoacetophenone reaction and which is more strongly bound than free nicotinic acid and liberated only after hydrolysis with $\mathrm{NaOH}$ ' (Kodicek, I940) has been confirmed by a number of workers (see review by Kodicek, 195 I $a$ ). This 'bound' form of nicotinic acid is only partly available to Lactobacillus arabinosus and Lactobacillus casei (Krehl \& Strong, 1944; Kodicek \& Pepper, 1948; Clegg, Kodicek \& Mistry, 1952). Microbiological and chemical evidence indicates that almost all the nicotinic acid in cereals, such as maize, wheat, barley, rye and rice, is present in this alkali-labile, 'bound' form, that differs from the known nicotinoyl derivatives (see Kodicek, I95 I $a$ ).

This 'bound' form of nicotinic acid does not appear to serve as a source of the vitamin for the nicotinic acid-deficient rat (Chaudhuri \& Kodicek, 1950a; Kodicek, 195r b), chick (Krehl, Elvehjem \& Strong, I944; Coates, Ford, Harrison, Kon, Shepheard \& Wilby, 1952) and duck (Heuser \& Scott, I953). Experiments with pigs, in which a deficiency of nicotinic acid was produced on diets containing a large proportion of maize (Birch, Chick \& Martin, 1937; Chick, Macrae, Martin \& Martin, I $938 a, b$; Braude, Kon $\&$ White, I946) suggest, by implication, that the 'bound' form is equally unavailable to the pig. On the other hand, dogs seemed to utilize a charcoal adsorbate of a partly purified preparation from wheat bran (Krehl et al. I944). There is no direct evidence about the availability to man of the 'bound' form. Holman (1954) 
observed, however, that children eating wholemeal bread tended to excrete less nicotinic-acid metabolites than those receiving a similar amount of nicotinic acid from vitamin-enriched white bread, which suggests that the 'bound' form is less available to them.

The full biological activity for the rat of 'bound' nicotinic acid in cereals can be released by hydrolysis with $0.5 \mathrm{~N}-\mathrm{NaOH}$ (Chaudhuri \& Kodicek, I950a; Kodicek, $\mathrm{I} 95^{\mathrm{I}} b$ ), but again it is uncertain whether this procedure makes the nicotinic acid available to man. If it were so, alkali treatment could be a possible way of 'enrichment' of the foodstuff. In this connexion, treatment of maize with lime-water has been reported to cure nicotinic-acid deficiency in rats (Laguna \& Carpenter, I95 I C Cravioto, Massieu, Cravioto \& Figueroa, 1952). It is possible, therefore, that lime-water treatment of maize as practised in Mexico may be responsible for the low incidence of pellagra among maize eaters there. However, in other laboratories this mitigating effect of treatment with lime-water has not been observed for either the rat (Krehl, Henderson et al. 1946) or man (Goldsmith, Gibbens, Rosenthal, Unglaub \& Miller, 1954; Goldsmith, Rosenthal, Gibbens \& Unglaub, 1955). Recently, evidence has been obtained indicating that the effectiveness of lime-water treatment in producing a maize preparation that would cure nicotinic-acid deficiency depends on the extent to which the 'bound' nicotinic acid has been liberated. This liberation depends on the conditions of the treatment (Kodicek, 1955, unpublished).

In view of the similarity of the nicotinic-acid metabolism of the pig to that of man (Birch et al. 1937), we considered that experiments on the pig might throw light on conditions in man. A preliminary account of the present study has already been given (Braude, Kon, Mitchell \& Kodicek, I955).

\section{EXPERIMENTAL}

\section{Design of experiment}

The aim of the investigation was to ascertain the effect of hydrolysis with $\mathrm{NaOH}$ on the pellagragenic activity of maize and on the liberation of nicotinic acid present in it in 'bound' form. In addition to the animal experiment, the constituents of the diets were analysed for their nicotinic-acid content, free or 'bound', by microbiological and paper-chromatographic procedures.

The experiment with pigs was divided into two periods. In the preliminary stage all the pigs received a maize diet deficient in nicotinic acid, shown in Table $\mathbf{I}$ (diet 0 ). This preliminary deficiency period varied from pig to pig, and only when an animal ceased to gain or lost weight for three consecutive weighings, i.e. for 7 days, was it put on the experiment proper and given the experimental diet according to the group to which it had been assigned at the beginning of the experiment. The pigs in group I served as deficient controls and were maintained on the deficient diet, modified only by replacing the whole maize with maize reconstituted from its milling fractions (see p. 53) (diet I, Table I). Group 2, positive controls, received diet I supplemented with 6 mg nicotinic acid daily; the dose was dissolved in $2 \mathrm{ml}$. water and given by mouth. Group 3 was given diet 2 ('Table $\mathrm{I}$ ) in which two of the milling fractions of the maize, namely 
hominy meal and bran, containing $73 \%$ of the total nicotinic acid, had been hydrolysed with $0.5 \mathrm{~N}-\mathrm{NaOH}$ to liberate 'bound' nicotinic acid. The animals were maintained on these diets for 9 weeks or until they succumbed to deficiency.

Table I. Percentage composition of diets used in the preliminary deficiency period and in the experiment proper

\begin{tabular}{|c|c|c|c|}
\hline Constituent & Diet o* & Diet $I^{*}$ & Diet $2 *$ \\
\hline Maize, white, ground & 79 & - & 一 \\
\hline \multicolumn{4}{|l|}{ Reconstituted maize: } \\
\hline Graded grits & - & 32.5 & $31 \cdot 0$ \\
\hline Grits from hominy & - & $25 \cdot 5$ & $25 \cdot 5$ \\
\hline Hominy meal and bran, mixed & - & $21 \cdot 0$ & - \\
\hline Hydrolysed hominy meal and bran, mixed & - & - & $2 r \cdot 0 f$ \\
\hline Pea meal & 10.5 & $10 \cdot 5$ & $10 \cdot 5$ \\
\hline Casein & $5^{\circ} 0^{\circ}$ & $5^{\circ} \circ$ & $5^{\circ} \circ$ \\
\hline Cod-liver oil & $3 \cdot 0$ & $3 \cdot 0$ & 3.0 \\
\hline Salt mixture $f$ & $2 \cdot 0$ & $2 \cdot 0$ & $2 \cdot 0$ \\
\hline $\mathrm{NaCl}$ & 0.5 & 0.5 & $2 \cdot 0 \S$ \\
\hline
\end{tabular}

* Diet $\mathrm{o}=$ diet for all groups in preliminary deficiency period; diet $\mathrm{I}=\operatorname{diet}$ for negative control group (group I) and for nicotinic acid-supplemented group (group 2); diet $2=\operatorname{diet}$ for the group given the hydrolysed maize fraction (group 3 ).

$\dagger$ Net weight, corrected for salt content.

$\$$ Calcium carbonate 200 , bone ash 200 , ferric oxide $8 \mathrm{~g}$.

$\S \mathrm{NaCl}$ from the hydrolysed maize fraction.

\section{Animals}

Eighteen weanling pigs (nine of each sex) from four litters, weighing $37-59 \mathrm{lb}$., were assigned at the beginning of the preliminary period to one of the three groups. Littermates were assigned to treatments by lot. The pigs were kept in separate pens, on concrete floors without bedding and were offered dry food without stint. Water was available at all times. The weight of the pigs was recorded twice weekly, and the food intake daily.

\section{Diets}

General. The diets used in the preliminary deficiency period and in the experiment proper are shown in Table I. They were those of Braude et al. (1946) with modifications mentioned on p. $5^{2}$.

Preparation of hydrolysed fraction of mixed hominy meal and bran. The amount of maize required for hydrolysis was estimated to be more than I ton. Treatment of such a large quantity was not practicable in our laboratories.

It was decided to obtain separate milling fractions of maize and to hydrolyse only those containing the greater part of the nicotinic acid of maize (cf. Heathcote, Hinton \& Shaw, 1952). The treatment of only part of the maize grain reduced the bulk and had the further advantage that a large proportion of starch was not treated with $\mathrm{NaOH}$, obviating the complications of possible nicotinic-acid sparing action of breakdown products of starch (Krehl, Sarma, Teply \& Elvehjem, I946). The Directors of Quaker Oats Ltd, Southall, Middlesex, kindly placed the facilities of their factory at our disposal. They arranged for the milling of $\mathrm{I} \frac{1}{4}$ tons of white maize into four fractions, 
namely graded grits $(4 \mathrm{I} \cdot \mathrm{I} \%$ of the total), grits from hominy $(32 \cdot 3 \%)$, hominy meal and bran. The last two were mixed and treated as one fraction $(26.6 \%$ of the total). The first two fractions were derived mainly from the endosperm. The hominy meal and bran included the greater part of the aleurone layer, the richest source of nicotinic acid, and contained about $73 \%$ of the total nicotinic acid in the grain.

For hydrolysis, $265 \mathrm{lb}$. of the mixed hominy meal and bran fractions were finely ground and mixed with $4001.0 .5 \mathrm{~N}-\mathrm{NaOH}$ in a rotating tank heated by steam to a pressure of $\mathrm{io} \mathrm{lb}$./sq. in. for $45 \mathrm{~min}$. When the tank was opened, the inside temperature of the material was found to be $60^{\circ}$. The mixture was brought to $\mathrm{pH} 7$ with 10 1. conc. $\mathrm{HCl}$ and dried in a heating tunnel at $70^{\circ}$. The hydrolysed material contained $10 \% \mathrm{NaCl}$ and this excess salt was partly offset by omitting additional $\mathrm{NaCl}$ from diet 2 (Table $\mathrm{r}$ ). The chemical composition of all ingredients of the diets and their vitamin and tryptophan content are shown in Tables 2-5. The nicotinic acid was found to be in free form, as discussed below.

Table 2. Nicotinic-acid content of unhydrolysed and hydrolysed maize fractions and of pea meal

\begin{tabular}{|c|c|c|c|c|}
\hline \multirow[b]{3}{*}{ Fraction or constituent } & \multicolumn{4}{|c|}{ Nicotinic acid $(\mu \mathrm{g} / \mathrm{g})$} \\
\hline & \multirow{2}{*}{$\begin{array}{l}\text { Unhydro- } \\
\text { lysed extract, } \\
\text { micro- } \\
\text { biological } \\
\text { test }\end{array}$} & \multicolumn{3}{|c|}{ Hydrolysed extract (total nicotinic acid) } \\
\hline & & $\begin{array}{l}\text { Micro- } \\
\text { biological } \\
\text { test }\end{array}$ & $\begin{array}{c}\text { Chemical } \\
\text { test }\end{array}$ & Mean \\
\hline $\begin{array}{l}\text { Hominy meal and bran, mixed } \\
\text { Hydrolysed hominy meal and bran, mixed } \\
\text { Graded grits } \\
\text { Grits from hominy }\end{array}$ & $\begin{array}{r}7 \cdot 4 \\
42 \cdot 8 \\
I \cdot 6 \\
2 \cdot 4\end{array}$ & $\begin{array}{r}37 \cdot 8 \\
41 \cdot 6 \\
4 \cdot 8 \\
6 \cdot 9\end{array}$ & $\begin{array}{r}40 \cdot 8 \\
44 \cdot 3 \\
3 \cdot 9 \\
6 \cdot 3\end{array}$ & $\begin{array}{r}39 \cdot 3 \\
42 \cdot 9 \\
4 \cdot 4 \\
6 \cdot 6\end{array}$ \\
\hline $\begin{array}{l}\text { Maize: reconstituted* } \\
\text { original }\end{array}$ & $\begin{array}{l}3.4 \\
4 \cdot 4\end{array}$ & $\begin{array}{l}14 \cdot 3 \\
13 \cdot 9\end{array}$ & $\begin{array}{l}14 \cdot 5 \\
15.5\end{array}$ & $\begin{array}{l}14 \cdot 4 \\
14 \cdot 7\end{array}$ \\
\hline Pea meal & $17 \cdot 6$ & 16.9 & I $1 \cdot 6$ & $14 \cdot 5$ \\
\hline
\end{tabular}

* Calculated from analyses of milling fractions.

Table 3. Vitamin and tryptophan content of maize fractions and diet constituents

\begin{tabular}{|c|c|c|c|c|c|c|}
\hline \multirow[b]{2}{*}{ Fraction or constituent } & \multicolumn{2}{|c|}{$\begin{array}{l}\text { Nicotinic acid* } \\
(\mu \mathrm{g} / \mathrm{g})\end{array}$} & \multirow{2}{*}{$\begin{array}{c}\text { Trypto- } \\
\text { phan } \\
(\mathrm{mg} / \mathrm{g})\end{array}$} & \multirow{2}{*}{$\begin{array}{c}\text { Thiamine } \\
(\mu \mathrm{g} / \mathrm{g})\end{array}$} & \multirow{2}{*}{$\begin{array}{l}\text { Ribo- } \\
\text { flavin } \\
(\mu \mathrm{g} / \mathrm{g})\end{array}$} & \multirow{2}{*}{$\begin{array}{c}\text { Panto- } \\
\text { thenic } \\
\text { acid } \\
(\mu \mathrm{g} / \mathrm{g})\end{array}$} \\
\hline & 'Bound' & Free & & & & \\
\hline Graded grits & $4 \cdot 4$ & $\circ$ & 0.64 & 0.17 & 0.12 & $I \cdot I$ \\
\hline Grits from hominy & $6 \cdot 6$ & 0 & 0.64 & $2 \cdot 14$ & 0.25 & $2 \cdot 4$ \\
\hline Hominy meal and bran, mixed & $39 \cdot 3$ & 0 & 0.85 & 2.99 & 0.84 & $4 \cdot 0$ \\
\hline $\begin{array}{l}\text { Hydrolysed hominy meal and } \\
\text { bran, mixed }\end{array}$ & 0 & $42 \cdot 9$ & - & $3 \cdot 26$ & 0.90 & $3 \cdot 2$ \\
\hline $\begin{array}{c}\text { Maize: reconstituted } \uparrow \\
\text { original }\end{array}$ & $\begin{array}{l}14.4 \\
14.7\end{array}$ & $\begin{array}{l}\circ \\
\circ\end{array}$ & $\begin{array}{l}0.69 \\
0.67\end{array}$ & $I^{\cdot} 56$ & $\begin{array}{l}0.35 \\
0.40\end{array}$ & $2 \cdot 3$ \\
\hline Pea meal & $\circ$ & 14.5 & $2 \cdot 79$ & $\begin{array}{r}4.6 \\
<0.7\end{array}$ & $2 \cdot 97$ & $\begin{array}{r}9.7 \\
<0.2\end{array}$ \\
\hline
\end{tabular}

* Values represent means of chemical and microbiological estimations (see Table 2 ). The nicotinicacid content of fraction 'hominy meal and bran, mixed' was taken as the mean of $39^{\circ} 3$ and $42^{\circ} 9$, i.e. $4 \mathrm{I} \cdot \mathrm{I} \mu \mathrm{g} / \mathrm{g}$.

$\uparrow$ Calculated from analysis of milling fractions. 
Table 4. Percentage of total amounts of vitamins and tryptophan contained in various milling fractions of maize

\begin{tabular}{|c|c|c|c|c|c|c|}
\hline Fraction & of grain & acid & phan & Thiamine & Riboflavin & acid \\
\hline Graded grits & $4 \mathrm{I} \cdot \mathrm{I}$ & $12 \cdot 6$ & 26 & 5 & 14 & 19 \\
\hline Grits from hominy & $32 \cdot 3$ & $\mathrm{I} 4 \cdot 8$ & 20 & 44 & 23 & 33 \\
\hline $\begin{array}{l}\text { Hominy meal and } \\
\text { bran, mixed }\end{array}$ & 26.6 & $72 \cdot 6$ & 54 & $5 \mathrm{I}$ & 63 & $4^{8}$ \\
\hline $\begin{array}{l}\text { Hydrolysed hominy } \\
\text { meal and bran, } \\
\text { mixed }\end{array}$ & $26 \cdot 6$ & $79 \cdot 0$ & - & $5^{6}$ & 68 & $4 \mathrm{I}$ \\
\hline
\end{tabular}

Table 5. Percentage chemical composition of maize fractions and diet constituents

\begin{tabular}{|c|c|c|c|c|c|c|c|}
\hline Fraction or constituent & $\begin{array}{l}\text { Per- } \\
\text { centage of } \\
\text { original } \\
\text { maize }\end{array}$ & Moisture & $\begin{array}{l}\text { Crude } \\
\text { protein }\end{array}$ & Oil & $\begin{array}{l}\text { Soluble } \\
\text { carbo- } \\
\text { hydrate }\end{array}$ & Fibre & Ash \\
\hline Graded grits & $4 I^{\prime} \cdot I$ & $13 \cdot 2$ & $7 \cdot 6$ & 0.7 & $78 \cdot 1$ & $0 \cdot 1$ & 0.1 \\
\hline Grits from hominy & $32 \cdot 3$ & $12 \cdot 2$ & $8 \cdot I$ & $2 \cdot 6$ & $75 \cdot 9$ & 0.4 & 0.8 \\
\hline $\begin{array}{l}\text { Hominy meal and bran, } \\
\text { mixed }\end{array}$ & $26 \cdot 6$ & $10 \cdot 4$ & $10 \cdot 0$ & II 3 & $59 \cdot 7$ & $6 \cdot I$ & $2 \cdot 5$ \\
\hline $\begin{array}{l}\text { Hydrolysed hominy meal } \\
\text { and bran, mixed }\end{array}$ & $26 \cdot 6$ & 10.6 & - & $7 \cdot 0$ & - & - & - \\
\hline Maize, reconstituted* & $100 \cdot 0$ & $12 \cdot 2$ & $8 \cdot 5$ & $4 \cdot 0$ & $73^{\circ} \mathrm{I}$ & $r \cdot 8$ & $I \cdot 0$ \\
\hline Pea meal & - & 13.9 & $23 \cdot 0$ & $I \cdot O$ & $52 \cdot 2$ & 6.9 & $3 \cdot 0$ \\
\hline Casein & - & $6 \cdot 3$ & $9 \times \cdot 5$ & 0.1 & - & - & \\
\hline
\end{tabular}

* Calculated from analyses of milling fractions.

Table 6 shows the vitamin, tryptophan and nutrient content of the diets used in the experiment. Diet o given to all groups in the preliminary deficiency period and diet $\mathbf{I}$ given to groups $\mathrm{I}$ and 2 in the experiment proper had $5.98 \mathrm{mg}$ nicotinic acid/lb., almost all in 'bound' form. The small amount of free nicotinic acid was derived from pea meal. Diet 2 given to group 3, had the same amount of nicotinic acid, but $77 \%$ in free form, owing to the hydrolysis of the hominy meal and bran fraction.

\section{Table 6. Nutrient content of diets}

\begin{tabular}{|c|c|c|}
\hline & & $\begin{array}{c}\text { Diet } 2^{*} \\
\text { (hydrolysed } \\
\text { maize fraction) }\end{array}$ \\
\hline $\begin{array}{l}\text { Nutrient } \\
\text { Protein (g/lb.) } \\
\text { Carbohydrate (g/lb.) }\end{array}$ & $62 \cdot 3$ & $\begin{array}{c}61 \cdot 4 \\
680 \cdot 0\end{array}$ \\
\hline \multicolumn{3}{|l|}{ Nicotinic acid: } \\
\hline 'Bound' (mg/lb.) & $5 \cdot 33$ & $1 \cdot 38$ \\
\hline Free (mg/lb.) & 0.65 & 4.57 \\
\hline Total (mg/lb.) & 5.98 & $5 \cdot 95$ \\
\hline Tryptophan (mg/lb.) & 618.0 & 618.0 \\
\hline Thiamine (mg/lb.) & 0.76 & 0.79 \\
\hline Riboflavin (mg/lb.) & 0.27 & 0.28 \\
\hline Pantothenic acid (mg/lb.) & $1 \cdot 33$ & $1 \cdot 25$ \\
\hline
\end{tabular}

* Diet $o=$ pellagragenic maize $\operatorname{diet} ; \operatorname{diet} I=$ reconstituted maize diet ; diet $2=$ reconstituted maize diet in which the hominy meal and bran fraction had been hydrolysed with $0.5 \mathrm{~N}-\mathrm{NaOH}$. 


\section{Analytical methods}

Estimation of nicotinic acid. Every constituent of the diet was analysed for its content of nicotinic acid, 'bound' or free. The total nicotinic acid was estimated chemically by a modification of the method of Wang \& Kodicek (I943) and microbiologically with $L b$. casei (Clegg et al. 1952). The 'bound' nicotinic acid was estimated by testing, microbiologically, $\mathrm{O} \cdot \mathrm{I} \mathrm{N}-\mathrm{HCl}$ extracts of the material, without prior hydrolysis with strong acid or alkali, and the value so obtained was compared with the results for an alkali-hydrolysed extract. The 'bound' nicotinic acid in cereals gives only a small response, about $20 \%$ of that shown by a totally hydrolysed extract in which nicotinic acid is free (Kodicek \& Pepper, I948; Clegg et al. 1952).

The results of these analyses are shown in Table 2 . It will be seen that mixed hominy meal and bran, graded grits and grits from hominy, each gave a small response when tested in unhydrolysed extracts prepared with $0.1 \mathrm{~N}-\mathrm{HCl}$. The response increased three- to five-fold when extracts, hydrolysed with $\mathrm{N}-\mathrm{NaOH}$ for $30 \mathrm{~min}$ at $100^{\circ}$, were tested. In contrast, the mixed hominy meal and bran, which had been hydrolysed on a large scale with $0.5 \mathrm{~N}-\mathrm{NaOH}$ for feeding to pigs (see p. 54), showed a full microbiological response whether or not the extracts used for assay were again hydrolysed, the values being $42 \cdot 8$ and $4 \mathrm{r} \cdot 6 \mu \mathrm{g} / \mathrm{g}$ respectively. Similarly, with pea meal there was no difference between hydrolysed and unhydrolysed extracts. This finding indicated that in pea meal and in hydrolysed hominy meal and bran the nicotinic acid was readily available to $L b$. case $i$ and can be considered free.

The mean nicotinic-acid content of the dietary constituents is given in Table 3 . The calculated nicotinic-acid content of the reconstituted maize tallied well with that of the original maize grain and with the value of $14.2 \mu \mathrm{g} / \mathrm{g}$ found in maize by Heathcote $e$ al. (1952). In Table 4 is shown the percentage distribution of nicotinic acid between the various milling fractions of maize. The bulk of nicotinic acid in 'bound' form, was present in the fraction containing hominy meal and bran, mixed.

Paper-chromatographic method used for differentiating 'bound' and free nicotinic acid. The microbiological test gave only semi-quantitative indication of the presence or absence of the 'bound' form of nicotinic acid. It was therefore necessary to have independent evidence that maize, in common with wheat grain and rice (Chaudhuri \& Kodicek, 1949, 1950 $b$; Reddi, 1952; Chaudhuri, 1953), in fact contained no free nicotinic acid since the interpretation of the results was based on this premise. Furthermore, it has been claimed by Reddi ( $195^{2}$ ) that, according to paper-chromatographic results, maize preparations contain only free nicotinic acid. The method used by Reddi (1952) resulted, however, in a concentrate of high acidity, which would be expected to split the 'bound' form. The procedure was therefore modified by removing $\mathrm{HCl}$ by an ion-exchanger, as described below.

The material to be examined $(5 \mathrm{~g})$ was extracted for $\mathrm{I} h$ under reflux on a water-bath at $100^{\circ}$ with $20 \mathrm{ml} .80 \%(\mathrm{v} / \mathrm{v})$ methanol containing $\mathrm{HCl}$ to a final concentration of O.I N. The mixture was centrifuged, the supernatant liquid collected and the residue re-extracted in the same way, once with $20 \mathrm{ml}$. and twice with $10 \mathrm{ml}$. acidic $80 \%$ methanol. The combined extracts were evaporated on a water-bath to half their 
volume (c. $30 \mathrm{ml}$.), and $55 \mathrm{ml}$. water were added. The solution was mixed with activated Deacidite G (Permutit Co. Ltd, London), the amount of which was adjusted to give a $\mathrm{pH}$ of 6.8 . After centrifugation and collection of the supernatant liquid, the residue was washed three times with $15 \mathrm{ml}$. O I M M-acetic acid. The combined supernatant liquids were evaporated to dryness under reduced pressure. The dried material was dissolved in $2 \mathrm{ml}$. water. The final extract was used for paper chromatography, performed according to Kodicek \& Reddi (I95I). Descending and ascending chromatograms were run for I $6 \mathrm{~h}, n$-butanol saturated with water being used as the developing solvent. The dried chromatograms were exposed to $\mathrm{CNBr}$ vapour and sprayed with $2 \% p$-aminobenzoic-acid reagent (Kodicek \& Reddi, r 951 ).

The chromatograms of extracts obtained from mixed hominy meal and bran are shown in Pl. I. It can be seen that sample I (final extract) had only one coloured, yellow fluorescent spot at the origin, indicating the presence of 'bound' nicotinic acid, which does not move from the origin (Kodicek \& Reddi, I95I). No spot was seen in the $R_{F}$ region where free nicotinic acid would be expected. A second spot (free nicotinic acid) appeared in sample 2, which was the original extract to which I $\mu \mathrm{g}$ nicotinic acid had been added. Sample 3 was the original extract, hydrolysed with $\mathrm{N}-\mathrm{NaOH}$ for $15 \mathrm{~min}$ at room temperature and neutralized with $\mathrm{HCl}$ before application on paper. Here, only the free nicotinic-acid spot appeared, in the same region as in sample 4, which consisted of the hydrolysed extract to which I $\mu \mathrm{g}$ nicotinic acid had been added. The higher $R_{F}$ of free nicotinic acid in samples 3 and 4 was due to the greater salt content of the material. These results confirm the microbiological evidence ('Table 2) that the fraction, hominy meal and bran, contained originally only 'bound' and no free nicotinic acid. The extracts prepared by the original procedure of Reddi (1952) resulted in chromatograms in which there was only free nicotinic acid, evidently liberated by the prolonged heating on evaporation of the acidic-methanol solution.

Owing to losses by adsorption on the ion-exchange resin, the yield of nicotinic acid in the final extract was only $43 \%$ of the original content of the maize fraction. It might be supposed that the small yield was caused by the preferential adsorption of free nicotinic acid, if it were present originally. However, that it was not so can be seen from Fig. I $A$ in which chromatograms of pea-meal extract, prepared in the same manner, are shown. Pea meal contained, by microbiological assay, only free nicotinic acid or amide (Tables 2 and 3 ); the spots of free nicotinic acid appeared in the chromatograms of sample $I$, together with a spot indicating a trace of free nicotinamide; no 'bound' nicotinic acid was observed. Hydrolysis of pea-meal extracts before chromatography did not change the pattern of the chromatograms (samples 3 and 4 ). The yield of nicotinic acid in the pea-meal extract after treatment with ionexchange resin was also $43 \%$. Finally, the chromatograms of the maize fraction, hydrolysed hominy meal and bran, which had been hydrolysed on a large scale for feeding to pigs, showed only free nicotinic acid (Fig. $\mathrm{x} B$ ), indicating that the largescale hydrolysis had split the 'bound' nicotinic acid. If preferential adsorption on the resin of free nicotinic acid had taken place, no spots of free nicotinic acid would have been observed in the last two materials. 
Estimation of other vitamins and tryptophan. Riboflavin was estimated chemically (Kodicek \& Wang, r949) and microbiologically (Clegg et al. 1952), pantothenic acid was determined microbiologically by the method of Roberts \& Snell (1946) on samples prepared by the enzyme-digestion method of Neilands \& Strong (1948), and thiamine estimations were made by the thiochrome method of Harris \& Wang (r94I). Tryptophan was estimated chemically by the method of Graham, Smith, Hier \& Klein (1947).
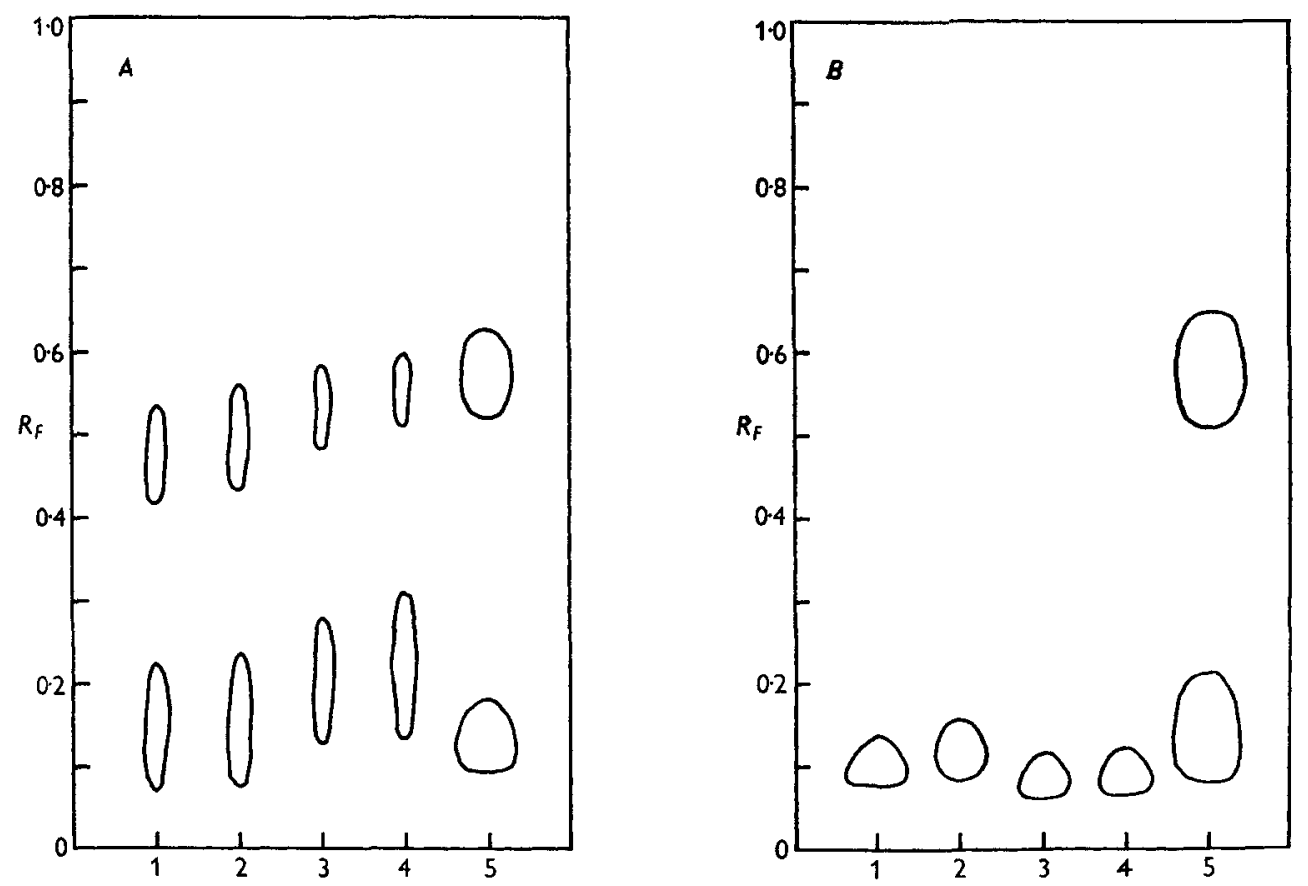

Fig. 1. Paper chromatograms of extracts of $(A)$ pea meal, $(B)$ mixed fraction 'hominy meal and bran', hydrolysed with $\mathrm{NaOH}$ for feeding to pigs. Solvent: $n$-butanol-water; ascending flow for $20 \mathrm{~h}$ on Whatman no. 1. Spots: $20 \mu \mathrm{l}$, detected by CNBr-p-aminobenzoic-acid reaction as yellowcoloured, fluorescent spots. I, unhydrolysed extract; 2 , unhydrolysed extract with $\mathrm{I} \mu \mathrm{g}$ nicotinic acid; 3 , alkali-hydrolysed extract; 4 , alkali-hydrolysed extract with I $\mu \mathrm{g}$ nicotinic acid; 5 , nicotinic acid and amide, I $\mu \mathrm{g}$ each.

The distribution of the vitamins (Tables 3 and 4 ) indicates that a considerable portion of the thiamine-rich layers of the grain, such as the scutellum, had been included in the grits from hominy, which were not hydrolysed. Pantothenic acid and tryptophan were also evenly distributed between grits and the mixed fraction of hominy meal and bran; the mild alkaline hydrolysis of the latter, on a large scale, did not result in any appreciable decrease in vitamin content.

\section{RESULTS}

The individual growth curves of the pigs, their food consumption, intake of nicotinic acid, 'bound' or free, and of tryptophan are shown in Fig. 2, and mean values are plotted in Fig. 3 . 

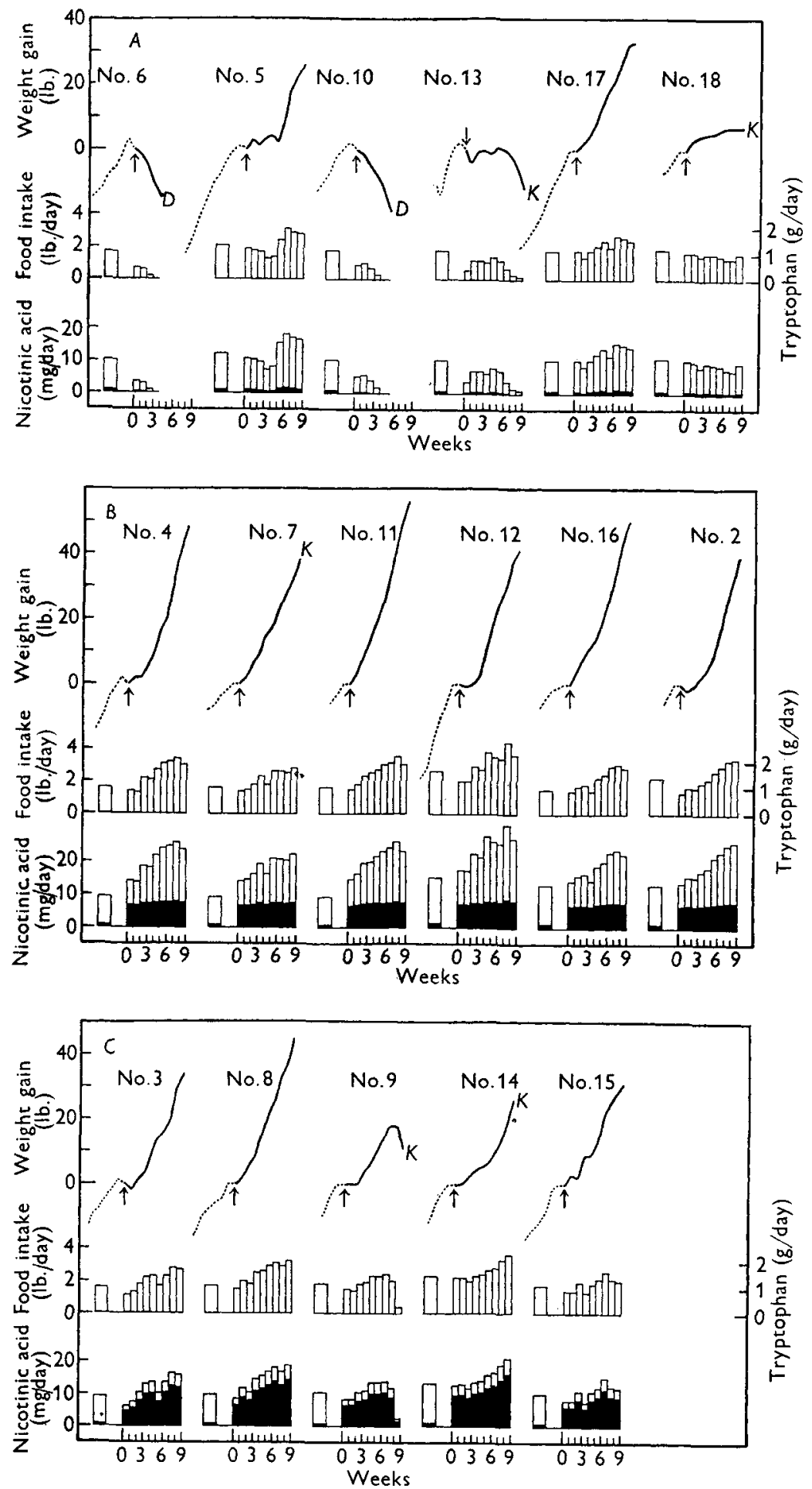

Fig. 2. Growth curves and daily intake of food, tryptophan and nicotinic acid of individual pigs of groups I-3. $A$, group I (deficient control pigs); $B$, group 2 (pigs given $6 \mathrm{mg}$ nicotinic acid daily); $C$, group 3 (pigs given alkali-hydrolysed maize fraction); ...., preliminary deficiency period; - , experiment proper; $\uparrow$, beginning of experiment proper; $D$, died; $K$, killed. Wide columns, daily intake of food, tryptophan and nicotinic acid for the whole preliminary deficiency period; narrow columns, daily intake during experiment proper calculated for I week. Top columns, intake of food (lb./day) and of tryptophan (g/day); lower columns, intake of total nicotinic acid (mg/day); black areas, free, available nicotinic acid (mg/day). 


\section{Preliminary deficiency period}

Fifteen pigs became deficient within $17-49$ days. Two pigs, nos. 5 and 17 , which had been assigned at the beginning of the experiment to the deficient control group I, required 63 and 59 days respectively to become deficient. They were consequently the heaviest ( 73 and $75 \mathrm{lb}$.) and oldest animals at the beginning of the experiment proper. One animal (no. I), which had been assigned to group 3, did not become deficient during the whole period of the test and was therefore not included. It became deficient only in the 14 th week and was killed in a moribund condition for autopsy.

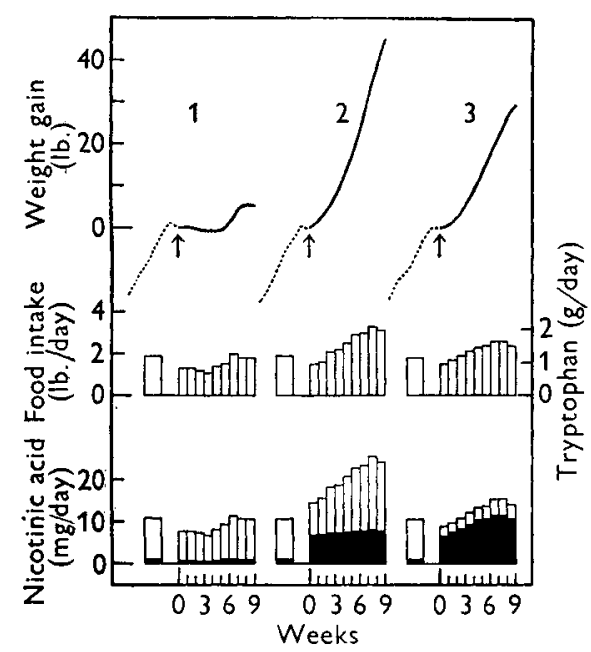

Fig. 3. Effect of alkaline hydrolysis of maize fractions (hominy meal and bran) on the availability to deficient pigs of nicotinic acid from maize. Mean growth curves and daily intake of food, tryptophan and nicotinic acid of pigs deficient in nicotinic acid given various treatments for 9 weeks. I, group I (deficient control pigs) (two pigs died in this group); 2, group 2 (pigs given 6 mg nicotinic acid daily); 3 , group 3 (pigs given the alkali-hydrolysed maize fraction). For explanations of symbols see Fig. 2.

Tables 7 and 8 show the average performance of the pigs and their intake of food constituents. The mean initial weight was similar for all three groups. The mean length of the preliminary period was greater in group I because two pigs took longer to become deficient. The mean gain in weight and food consumption in the preliminary period during which all the pigs received the same diet were remarkably even in the three groups and hence the intake of constituents varied little from one group to another.

Scouring developed in the last $2-3$ weeks of the preliminary period in all pigs; it persisted for almost the entire duration of the experiment proper in four of the six deficient control pigs of group I. Pig no. I7, which was late in becoming deficient, nevertheless scoured for 6 weeks before it was placed on the experiment proper. The pigs of groups 2 and 3 ceased scouring within $1-2$ weeks of the beginning of treatment. 


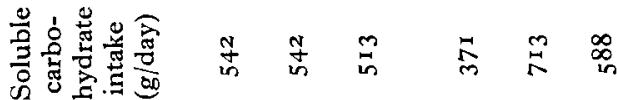

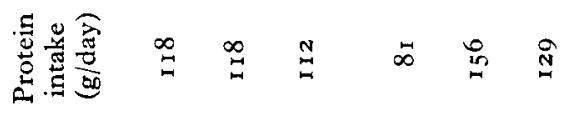

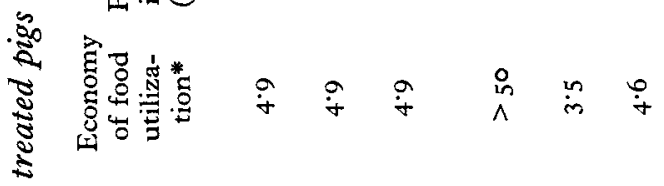

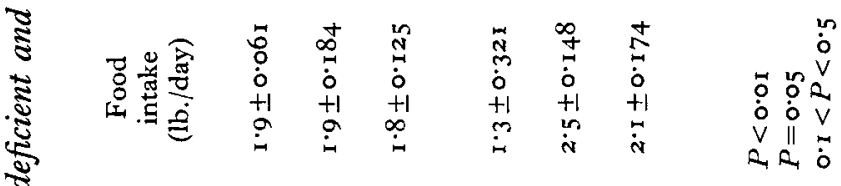

क

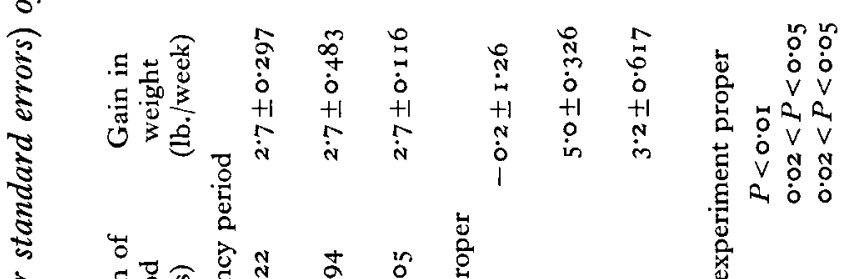

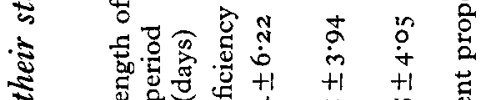

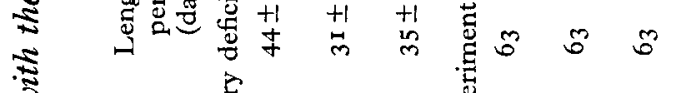

$\sqrt{\frac{3}{3}}$

है

$\stackrel{8}{8}$

จุะ

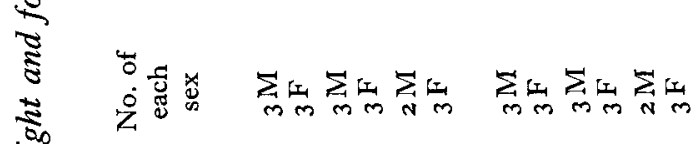

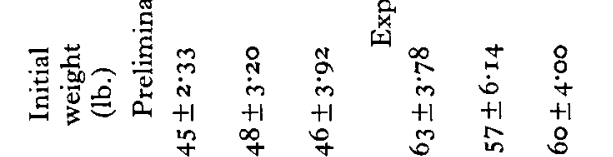

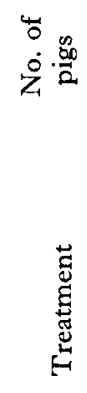

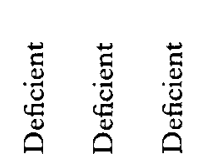

o 0 in

$\sqrt{\frac{\pi}{2}}$

$\stackrel{5}{8}$

竞

กั

$+\omega$
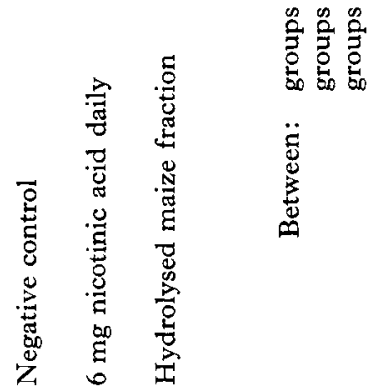

苛

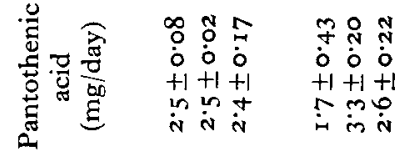

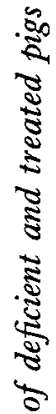

จุำ

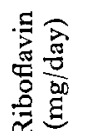

ชู

0

os

$+1+1+1 \quad+1+1+1$

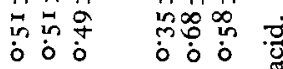

密

弯舍

की

$+1+1+1$

in

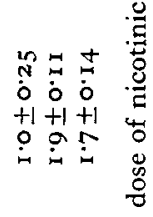

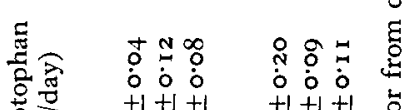

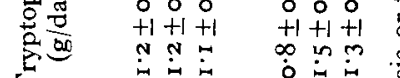

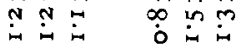

m:


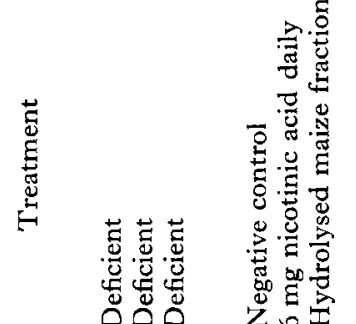

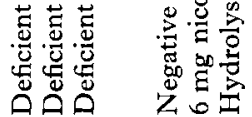

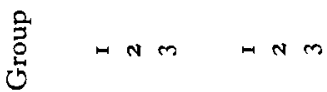




\section{Experiment proper}

The performance of the pigs after they had been on the experimental diets for 9 weeks is shown by individual and mean values in Figs. 2 and 3 .

The deficient control pigs lost, or did not gain, weight, and two died of deficiency on the $25^{\text {th }}$ and $3^{8 \text { th }}$ day respectively. Two other animals finished the experiment in a moribund state. The remaining pigs, nos. 5 and $I 7$, which had required an exceptionally long preliminary period before they ceased to grow, completed the experiment without showing signs of deficiency. One of them (no. 17) resumed growth within I week. This pig was placed on the experiment proper when, according to our definition (see p. 52), it was considered deficient. It may in fact, as pig no. I which was not included in the experiment, not have been depleted. The other pig (no. 5) at first ceased growing for 5 weeks but recovered towards the end of the experiment. Such an occasional recovery, especially of older and heavier pigs, has been observed before (Birch et al. 1937; Braude et al. 1946).

All the pigs given $6 \mathrm{mg}$ nicotinic acid daily (group 2) recovered from the deficiency within I-2 weeks, ceased scouring and gained steadily in weight (Figs. 2 and 3 ).

The pigs in group 3, given the alkali-hydrolysed maize fraction, also recovered and gained weight, though the improvement was slower than in group 2. One animal, no. 9 , stopped eating in the 9 th week of the experiment proper, lost weight and had to be killed on the last day of experiment. Post-mortem examination showed that the illness was not connected with nicotinic-acid deficiency as no active signs of deficiency were present, and moreover the pathological lesions in the intestine, caused by the deficiency in the preliminary period, were in the healing stage.

Tables 7 and 8 show the mean weight gain and intake of food, nicotinic acid, other vitamins and tryptophan. It will be seen that the deficient control pigs in group i lost on the average $0.2 \mathrm{lb}$./week, whereas the animals of groups 2 and 3 gained 5 and $3 \mathrm{lb}$./week respectively. Similarly, the food intake and economy of food utilization of pigs in groups 2 and 3 were significantly better than in group I. The differences in weight gain were significant between group I (deficient) and each of the groups 2 and 3 . The increase in weight of the nicotinic acid-supplemented group was significantly better than that of group 3 given the alkali-treated diet, but the food intake was not significantly different.

The deficient group I consumed on the average $7 \cdot 7 \mathrm{mg}$ nicotinic acid daily, of which only $0.8 \mathrm{mg}$ were considered to be available. The vitamin-supplemented group $2 \mathrm{had}$ $20.8 \mathrm{mg}$ total nicotinic acid daily, of which $7.6 \mathrm{mg}$ were available (made up of $\mathrm{r} \cdot 6 \mathrm{mg}$ from pea meal and $6 \mathrm{mg}$ from the dose). Group 3, on the diet in which $73 \%$ of the nicotinic acid present in maize had been liberated by alkaline hydrolysis, had daily $9.6 \mathrm{mg}$ nicotinic acid in available form out of a total of $12.6 \mathrm{mg}$. This total intake may be contrasted with the total intake of $10.8 \mathrm{mg}$, but almost all in 'bound' form, of the same pigs in the preliminary period during which the animals became deficient.

The mean daily intake of tryptophan was $0 \cdot 8, I \cdot 5$ and $\mathrm{I} \cdot 3 \mathrm{~g}$ in groups $\mathrm{I}, 2$ and 3 respectively, compared with an intake of $\mathrm{I} \cdot \mathrm{I}-\mathrm{I} \cdot 2 \mathrm{~g}$ in the preliminary deficiency period (Table 8). 
The mean daily intake of thiamine of groups 2 and 3 was $1 \cdot 9$ and $1 \cdot 7 \mathrm{mg}$ compared with the reputed requirement of ${ }^{\prime} \cdot 77 \mathrm{mg}$ (see Braude, 1954). The intake of riboflavin and of pantothenic acid was low, 0.68 and $0.58 \mathrm{mg}$ and 3.3 and $2.6 \mathrm{mg}$ respectively, compared with the daily requirements published in the literature, namely $2.7 \mathrm{mg}$ for riboflavin and $17.7 \mathrm{mg}$ for pantothenic acid (see Braude, 1954).

\section{Post-mortem findings}

Mr R. M. Loosmore and Mr D. Buntain of the Ministry of Agriculture, Fisheries and Food Veterinary Investigation Centre, Reading, carried out autopsy on the pigs, and the salient points of their findings are as follows.

Group I (deficient controls). Pigs nos. 6, io and I3 were examined. The carcasses were in poor condition, the skin dirty, hairy and greasy. Ulcerative gastritis and diffuse necrotic non-suppurative enteritis affecting the whole or part of the caecum and most of the colon were present. These signs are characteristic of nicotinic-acid deficiency (cf. Chick et al. 1938b; Braude et al. 1946; Luecke, McMillen, Thorp \& Tull, I947). In pig no. 6 necrotic ulcerations in the pharynx were observed.

Group 2 (6 mg nicotinic acid daily). At the end of the experiment all pigs appeared normal and were fattened off with the exception of one pig, no. 7 , which was killed for examination. The pig was found to be normal.

Group 3 (alkali-treated maize fractions). Two pigs, nos. 9 and 14 , were killed for examination at the end of the experiment; the remaining pigs were fattened off. Autopsy of the two pigs showed signs of healed lesions indicative of a previous deficiency of nicotinic acid. In addition, in pig no. 9 dystrophy of the adductor muscles of the thigh and, in both pigs, fatty infiltration of liver and kidneys were observed. These signs might have been associated with vitamin $\mathrm{E}$ deficiency as has been noted by Obel ( 1953 ). The deficiency may have been caused by partial destruction of vitamin $\mathrm{E}$ during the alkaline hydrolysis and subsequent drying of the maize fraction, although we have no experimental evidence to this effect.

\section{DISCUSSION}

The chemical and microbiological evidence presented shows that the nicotinic acid in maize, of which about $73 \%$ was in the two milling fractions of hominy meal and bran, is in 'bound' form. When these fractions were hydrolysed with $\mathrm{NaOH}$ before feeding to pigs, the hydrolysed material was found to have its nicotinic acid in free form.

The other maize fractions, graded grits and grits from hominy, together containing about $27 \%$ of the total nicotinic acid, were not studied by paper chromatography, but the microbiological results indicated the presence of 'bound' nicotinic acid. Since these fractions were not hydrolysed before feeding to pigs, it is assumed that their nicotinic acid remained in 'bound' form.

By analogy with the wheat grain (see review by Kodicek, $195 \mathrm{I} a$ ), it is likely that in maize the embryo contains nicotinic acid in free, available form; the amount derived therefrom would be, however, only about $1.7 \%$ of the total nicotinic acid (Heathcote et al. 1952), and it would not have been detected by the methods used in this study. 
The amount in $\mathrm{I} \mathrm{lb}$. of diet, $0.09 \mathrm{mg}$, would be negligible, and would not have contributed significantly to the supply of available nicotinic acid for the pigs; it was, therefore, not taken into consideration in the estimates of free nicotinic acid (see Table 6), particularly since the presence of free nicotinic acid in maize germ has not yet been definitely established. Thus it can be concluded that all or almost all of the nicotinic acid in maize is in 'bound', unavailable form.

The feeding trials resulted in a definite improvement in the pigs given the diet containing the alkali-treated maize fraction. It seems that the liberation of nicotinic acid, evidenced by microbiological response and chemical means, is connected with the curative effect of the alkali-treated maize fraction; this conclusion is in line with positive results of previous experiments on rats (Chaudhuri \& Kodicek, I950 $a$; Kodicek, I95 I $b$ ).

The intake of tryptophan has to be considered as a potential source of nicotinic acid as it has been shown that tryptophan can be converted to nicotinic-acid compounds in the pig (Luecke, McMillen, Thorp \& Tull, I948) as well as in other species (Krehl, Teply, Sarma \& Elvehjem, I945; Sarett \& Goldsmith, I947, 1949). It appears that a daily intake of up to $\mathrm{I} \cdot 2 \mathrm{~g}$ tryptophan did not prevent the pigs becoming nicotinicacid deficient in the preliminary period. It may be that, in the experiment proper, the nicotinic acid-supplemented pigs in group 2 benefited to a certain extent from an increased intake of tryptophan that rose to $\mathrm{r} \cdot 5 \mathrm{~g} / \mathrm{day}$.

The development of nicotinic-acid deficiency at a relatively high intake of tryptophan is in agreement with the findings of Luecke et al. (1948) who observed signs of deficiency in pigs on similar intakes. It seems that this amount of the amino-acid $(0.14 \%$ in the diet) was only sufficient to cover the daily requirement for protein metabolism; the suggested requirement of the pig, in presence of an adequate supply of nicotinic acid, is from 0.1 to $0.4 \%$ tryptophan in the diet (see Braude, 1954). The daily requirement of the pig for tryptophan is evidently much higher than that of man which has been assessed at $0.25 \mathrm{~g}$ (Rose, Lambert \& Coon, I954).

The pigs receiving the alkali-treated diet (group 3) grew less well than the positive controls, although they consumed more free nicotinic acid. No such differences were found for rats (Kodicek, 1955, unpublished), and we have at present no clear explanation to offer for the behaviour of the pigs, although it is possible that the higher intake of tryptophan, mentioned above, was, at least in part, responsible for the better performance of the pigs in group 2 whose diet was supplemented with nicotinic acid.

\section{Implications for human nutrition}

As pigs in many ways resemble man in their reactions to a deficiency of nicotinic acid, it is possible that the following considerations apply to man.

(I) If 'bound' nicotinic acid is not available to man, the factor that would determine the pellagra-preventive potency of a cereal would be its tryptophan content, and possibly its amino-acid contribution to the balance of amino-acids in the whole diet. Thus cereals rich in tryptophan, such as wheat, rice, barley and rye, would owe their nicotinic-acid sparing activity to their tryptophan content and balance of amino-acids, and not to their nicotinic acid which is not available. Maize would be pellagragenic because of its lack of tryptophan and because of its specific amino-acid composition. 
These defects would not be compensated by its relatively high content of nicotinic acid, since this is present in an unavailable, 'bound' form. There is therefore no need to postulate a toxic factor in maize to explain its pellagragenic properties. These considerations would explain the high incidence of pellagra on certain maize diets and the virtual absence of deficiency on rice diets; the reason for this difference was not explainable on the basis of their respective nicotinic-acid contents, the maize diets being apparently richer in the vitamin than the rice diet (Aykroyd \& Swaminathan, I940). If, however, the nicotinic acid were not available in either cereal, the beneficial effect of the rice diet would doubtless be due to its higher tryptophan content.

Attempts to breed maize with a high nicotinic-acid content (Richey \& Dawson, 1948, I95 I T Teas \& Newton, I95 I; Williams, I950; Anonymous, I950) are unlikely to lead to an improved nutritive value, since the increase would presumably also be in the 'bound' form. A better way of enrichment is the addition of nicotinic acid (Williams, 1950). Alkali treatment, which liberates the 'bound' nicotinic acid is a tempting possibility for 'enrichment' of cereals, particularly for countries where home-grown maize is consumed and where addition of nicotinic acid presents practical difficulties. Lime-water treatment, as practised in Mexico, is a possible way of preparation, but before it can be recommended as a means of making the nicotinic acid available, further study of the process is needed.

(2) The usual estimates of the nicotinic-acid requirement of man and animals include the nicotinic acid present in cereals, which supply about $30-50 \%$ of the total intake. If the 'bound' nicotinic acid is not available, the estimate given will be too high and should be reduced (Braude et al. 1955). A correct estimate may be of particular importance in assessing the amount of nicotinic acid to be added to cereals in an 'artificial enrichment' policy.

\section{SUMMARY}

I. Microbiological and paper-chromatographic examination showed that maize, in common with other cereals, has all or almost all its nicotinic acid in 'bound' form which is unavailable to micro-organisms and rats. Our results show that this 'bound' form is also not available to pigs.

2. Two milling fractions of maize, hominy meal and bran, which amounted to $26.6 \%$ of the total maize grain and contained most of the aleurone layer and about $73 \%$ of the total nicotinic acid, were hydrolysed with $0.5 \mathrm{~N}-\mathrm{NaOH}$ in order to liberate the 'bound' nicotinic acid.

3. A deficiency of nicotinic acid was produced in seventeen pigs given a diet based on maize. Five of the deficient pigs were then given for 9 weeks the deficient diet modified by replacing the maize with maize reconstituted from its milling fractions in which the hominy meal and bran had been hydrolysed. The animals recovered from the deficiency. A control group of six deficient pigs, maintained on the reconstituted maize diet with unhydrolysed hominy meal and bran, remained deficient. A third group of six animals on the same diet, but given daily $6 \mathrm{mg}$ nicotinic acid, recovered from the deficiency.

4. It is suggested that the liberation of nicotinic acid by alkaline hydrolysis, confirmed 
also by paper chromatography, was mainly responsible for the recovery of the deficient pigs when given a diet containing the alkali-hydrolysed milling fraction of maize, which had all its nicotinic acid in free form.

Dame Harriette Chick and the late Sir Charles Martin took a keen interest in this work, and we have derived much benefit from talks and discussions with them. The experiments would not have been possible without the generous assistance we received from Quaker Oats Ltd, Southall, Middlesex, who carried out the large-scale hydrolysis and preparation of the maize fractions. We are particularly grateful to $\mathrm{Mr} \mathrm{B}$. C. L. Summers and Mr J. J. Holt of that company for their willing help. We are greatly indebted to Mr R. M. Loosmore, B.V.Sc., M.R.C.V.S., and Mr D. Buntain, M.R.C.V.S., for the post-mortem examination of the pigs and to Dr J. E. Ford for the estimation of pantothenic acid. We wish also to thank Mr R. S. Barber and Mr P. Wilson for technical assistance.

\section{REFERENCES}

Anonymous (1950). Nutr. Rev. 8, 241.

Aykroyd, W. R. \& Swaminathan, M. (1940). Indian F. med. Res. 27, 667.

Birch, T. W., Chick, H. \& Martin, C. J. (1937). Biochem. F. 31, 2065.

Borrow, A., Fowden, L., Stedman, M. M., Waterlow, J. C. \& Webb, R. A. (1948), Lancet, $254,752$.

Braude, R. (1954). In Progress in the Physiology of Farm Animals, Vol. I, p. 40. [J. Hammond, editor.] London: Butterworth Scientific Publications.

Braude, R., Kon, S. K., Mitchell, K. G. \& Kodicek, E. (1955). Lancet, 269, 898.

Braude, R., Kon, S. K. \& White, E. G. (1946). Biochem. F. 40, 843 .

Chaudhuri, D. K. (1953). Sci. and Cult. 19, 409.

Chaudhuri, D. K. \& Kodicek, E. (1949). Biochem. F. 44, 343.

Chaudhuri, D. K. \& Kodicek, E. (1950a). Biochem. $\mathscr{f} .47$, xxxiv.

Chaudhuri, D. K. \& Kodicek, E. (1950b). Nature, Lond., 165, 1022.

Chick, H., Macrae, T. F., Martin, A. J. P. \& Martin, C. J. (1938a). Biochem. J. 32, 10.

Chick, H., Macrae, T. F., Martin, A. J. P. \& Martin, C. J. (1938b). Biochem. F. 32, 844.

Clegg, K. M., Kodicek, E. \& Mistry, S. P. (1952). Biochem. F. 50, 326.

Coates, M. E., Ford, J. E., Harrison, G. F., Kon, S. K., Shepheard, E. E. \& Wilby, F. W. (1952). Brit. F. Nutr. 6, 75 .

Cravioto, R. O., Massieu, G. H., Cravioto, O. Y. \& Figueroa, F. de M. (1952). F. Nutr. 48, 453.

Goldsmith, G. A., Gibbens, J., Rosenthal, H. L., Unglaub, W. G. \& Miller, O. N. (1954). Fed. Proc. r3, $45^{8}$.

Goldsmith, G. A., Rosenthal, H. L., Gibbens, J. \& Unglaub, W. G. (1955). F. Nutr. 56, 371.

Graham, C. E., Smith, E. P., Hier, S. W. \& Klein, D. (1947). J. biol. Chem. r68, 7 x.

Harris, L. J. \& Wang, Y. L. (I94I). Biochem. F. 35, 1050.

Heathcote, J. G., Hinton, J. J. C. \& Shaw, B. (1952). Proc. Roy. Soc. B, r39, 276.

Heuser, G. F. \& Scott, M. L. (1953). Poult. Sci. 32, 137.

Holman, W. I. M. (1954). In Spec. Rep. Ser. med. Res. Coun., Lond., no. 287, p. 92.

Kodicek, E. (1940). Biochem. F. 34, 712.

Kodicek, E. (195I a). Rep. Progr. Chem. 48, 276.

Kodicek, E. (195 I b). Biochem. F. 48, viii.

Kodicek, E. \& Pepper, C. R. (1948). F. gen. Microbiol. 2, 306.

Kodicek, E. \& Reddi, K. K. (r95 I). Nature, Lond., 168, 475.

Kodicek, E. \& Wang, Y. L. (1949). Biochem. F. 44, 340.

Krehl, W. A. (1949). Vitam. E Horm. 7, 1 I I.

Krehl, W. A., Elvehjem, C. A. \& Strong, F. M. (x944). F. biol. Chem. 156, 13.

Krehl, W. A., Henderson, L. M., de la Huerga, J. \& Elvehjem, C. A. (1946). F. biol. Chem. 166, 53 I.

Krehl, W. A., Sarma, P. S., Teply, L. J. \& Elvehjem, C. A. (1946). F. Nutr. 31, 85 .

Krehl, W. A. \& Strong, F. M. (1944). F. biol. Chem. 156, 1.

Krehl, W. A., Teply, L. J., Sarma, P. S. \& Elvehjem, C. A. (1945). Science, ror, 489.

Laguna, J. \& Carpenter, K. J. (I95I). F. Nutr. 45, 2 I.

Luecke, R. W., McMillen, W. N., Thorp, F. Jr. \& Tull, C. (1947). F. Nutr. 33, 25 I. 
E. KODIClK, R. BRAUDE, S. K. KON AND K. G. MI'TCIELL. Plate I AVAILABILITY TO PIG OF MAIZE NICOTINIC ACID

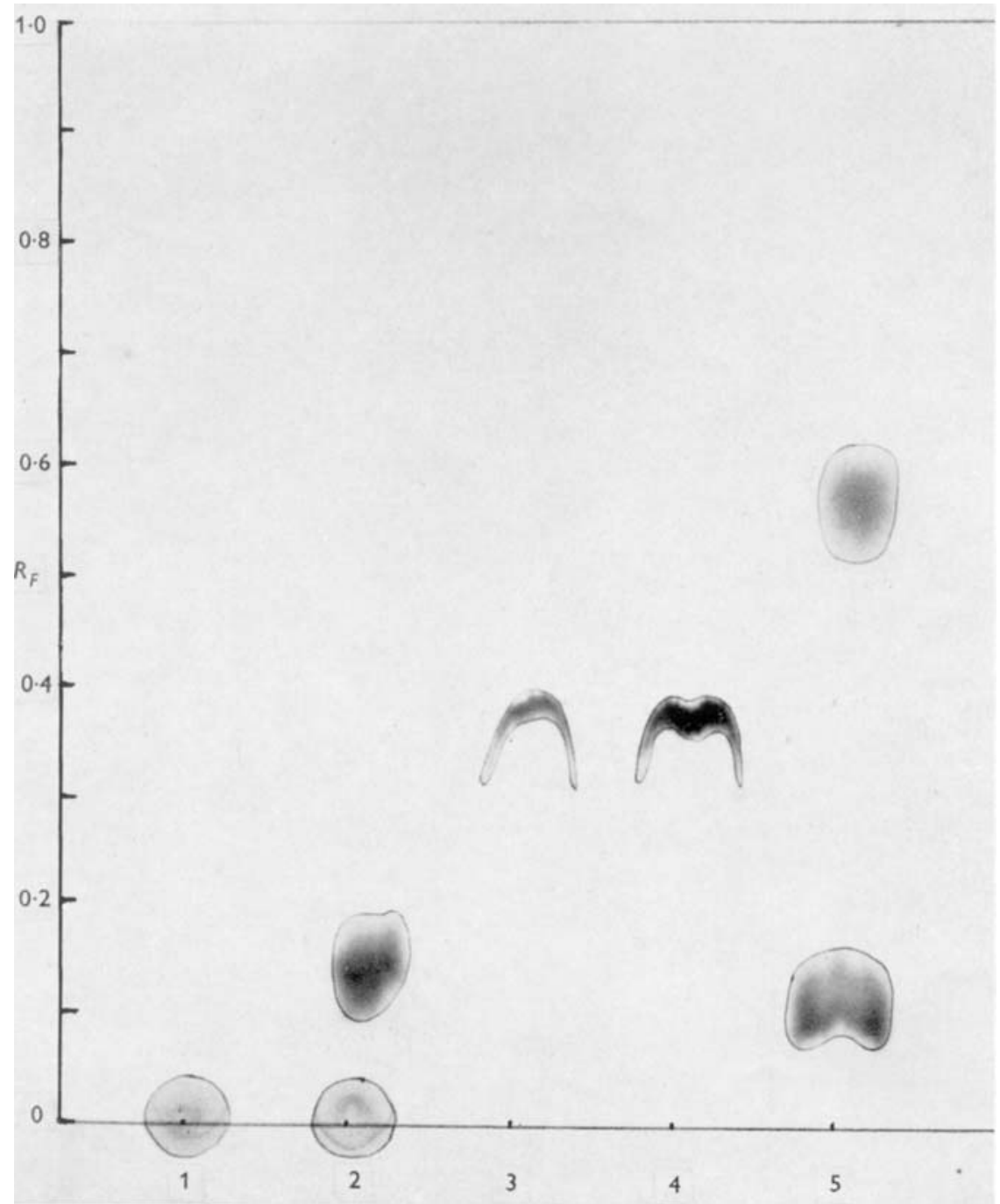

(liacing p. 67)

British Fournal of Nutrition, Vol. 1०, No. I 
Luecke, R. W., McMillen, W. N., Thorp, F. Jr. \& Tull, C. (1948). F. Nutr. 36, 4 I 7 .

Neilands, J. B. \& Strong, F. M. (1948). Arch. Biochem. 19, 287.

Obel, A. (1953). Acta path. microbiol. scand. Suppl. 94.

Reddi, K. K. (1952). Nature, Lond., r70, 745.

Richey, F. D. \& Dawson, R. F. (1948). Plant Physiol. 23, 238.

Richey, F. D. \& Dawson, R. F. (195I). Plant Physiol. 26, 475.

Roberts, E. C. \& Snell, E. E. (1946). F. biol. Chem. 163, 499.

Rose, W. C., Lambert, G. F. \& Coon, M. J. (1954). F. biol. Chem. $211,815$.

Sarett, H. P. \& Goldsmith, G. A. (1947). F. biol. Chem. 167, 293.

Sarett, H. P. \& Goldsmith, G. A. (1949). F. biol. Chem. 177, 461 .

Teas, H. J. \& Newton, A. C. (195I). Plant Physiol. 26, 494.

Wang, Y. L. \& Kodicek, E. (1943). Biochem. J. 37, 530.

Williams, R. R. (1950). Int. Z. Vitaminforsch. 22, 35.

Woolley, D. W. (1946). F. biol. Chem. 163, 773 .

\section{EXPLANATION OF PLATE}

Paper chromatogram of extracts of mixed fraction 'hominy meal and bran'. Solvent: $n$-butanol-water; ascending flow for $20 \mathrm{~h}$ on Whatman no. $\mathrm{x}$. Spots: $20 \mu 1$, , detected by CNBr- $p$-aminobenzoic-acid reaction as yellow-coloured, fluorescent spots. I, unhydrolysed extract; 2 , unhydrolysed extract with I $\mu$ g nicotinic acid; 3 , alkali-hydrolysed extract; 4 , alkali-hydrolysed extract with I $\mu g$ nicotinic acid; 5 , nicotinic acid and amide, $x \mu \mathrm{g}$ each. The higher $R_{F}$ of free nicotinic acid in spots 3 and 4 was due to the greater salt content of the material. 